\title{
NUMERICAL MODELING OF HEAT-AFFECTED ZONE IN GMAW PROCESS
}

\author{
H. R. GHAZVINLOO ${ }^{1,2}$, A. HONARBAKHSH-RAOUF ${ }^{1,2}$ \\ ${ }^{1}$ Department of Materials Engineering, Semnan University, Semnan, Iran; \\ ${ }^{2}$ Sava Sazeh Segal Industrial and Manufacturing Company, Semnan, Iran
}

\begin{abstract}
Low-carbon steel St37-2 is widely used in the bus production industry. The gas metal arc welding (GMAW) is strongly applied to join steel components due to its ease and low cost. Heat-affected zone (HAZ) is the area between the weld and base metal where can have the lowest toughness in a welding joint and hence it has always been a matter of interest for many researchers. This work aims to study the effects of GMAW parameters on HAZ width. The Taguchi orthogonal array, signal-to-noise $(\mathrm{S} / \mathrm{N})$ ratios, and analysis of variance (ANOVA) are employed to investigate and analyze the effect of the welding parameters on the HAZ width.
\end{abstract}

Keywords: St37-2 steel, gas metal arc welding, heat-affected zone, analysis.

Низьковуглецеві сталі St37-2 широко використовують в автомобілебудівній промисловості. Газодугове зварювання металу (ГДЗМ) успішно застосовують для зварювання сталевих елементів через його простоту та дешевизну. Зона термічного впливу (ЗТВ) - це ділянка між зварним з'єднанням та основним металом, де з'єднання може мати найменшу в'язкість і тому цікавить багатьох дослідників. Досліджено вплив параметрів ГДЗМ на ширину ЗТВ. Використано ортогональний масив Тагучі, відношення сигнал/шум (S/N) та дисперсійний аналіз (ANOVA) для аналізу впливу параметрів зварювання на ширину ЗТВ.

Ключові слова: сталь St37-2, газодугове зварювання, зона термічного впливу, аналіз.

Introduction. The gas metal arc welding (GMAW) process is an important component in many industrial operations [1]. This process has various advantages over other melting welding methods. High welding speed, large metal deposition, and spatter free welding are some of its advantages. In addition, it is applicable for a wide variety of commercial metals and alloys such as carbon steel, stainless steel, copper and aluminum. Furthermore, it is a mechanized method and allows the use of a robot [2-4]. These advantages have motivated many researchers to study the GMAW process in detail [5]. The heat-affected zone (HAZ) refers to a non-melted area adjacent to weld metal in the fusion welding processes which undergoes a lot of microstructural changes compared to the base metal. Several studies [6-11] have indicated that HAZ can have the lowest toughness in the weld joint and hence emphasize the importance of the HAZ. With increasing use of welded steel constructions, it became apparent that the HAZ showed susceptibility to various types of cracking, especially cold cracking which had been attributed to the formation of a very susceptible HAZ microstructure [12]. So, with considering all these problems, it makes sense that the minimizing of the HAZ width will only help. From what we know, there is relatively little information in order to minimize the HAZ width in low-carbon steels. Therefore, an attempt has been made in the present work to investigate and analyze the effect of GMAW parameters on the HAZ width in St37-2 steel.

Corresponding author. H. R. GHAZVINLOO, e-mail: Hamid.Ghazvinloo@gmail.com 
Materials and methods. Due to its industrial importance, DIN 17100 St37-2 steel was chosen as a base material in the form of a plate $3 \mathrm{~mm}$ thick. In addition, AWS A5.18/ER70S-6 copper-coated solid wire with $1 \mathrm{~mm}$ diameter and composition of $0.11 \mathrm{C}-1.63 \mathrm{Mn}-0.95 \mathrm{Si}-0.5 \mathrm{Cu}$ was used as a filling metal. To minimize the welding distortion, the plates were located in the jig fixtures and welded using the GMAW process as butt joints in a flat position. A Revo MIG SP 1601 machine was applied for welding operations in this study and weld pools were protected by $100 \% \mathrm{CO}_{2}$ shielding gas. The arc voltage (V), wire feeding speed (WFS), welding speed (WS) and torch angle (Alpha) were chosen as welding parameters at three levels and their effect on the HAZ width was investigated and analyzed. The welding parameters and their values at three levels are summarized in Table 1. Design of experiments (DOE) in this work was performed based on an application of Taguchi orthogonal array L9 in which the four variables were varied at three levels. The nine experiments designed based on Taguchi technique are summarized in Table 2. Having finished the welding process, the weld coupons were cut perpendicular to the welding direction in the same situations and the cross-sectional specimens were extracted. Then, these specimens were ground using SiC-papers, polished, and etched in $2 \%$ Nital for appearing the HAZ features. For each experiment, the HAZ widths were measured by caliper and the average width was reported. The analysis of variance (ANOVA) and signal-to-noise $(\mathrm{S} / \mathrm{N})$ ratios were applied to identify the most significant factor and predicted optimal parameters setting [13]. In this work the "smaller is better" criterion was selected for the HAZ width and the $\mathrm{S} / \mathrm{N}$ ratios were calculated. It means that the optimum level for a factor is the level that results in the lowest value of the $\mathrm{S} / \mathrm{N}$ ratio in the experimental region. As verification for the $\mathrm{S} / \mathrm{N}$ ratio results, the ANOVA was performed to determine the effect of different parameters on the output variable. Furthermore, contribution percentage of each control factor was determined from the results of ANOVA [14]. Finally, a mathematical model was established and utilized for predicting the HAZ width. For this purpose, a linear Regression model using Minitab 16 software was developed for finding the relationship between the predictor variables and the response variable.

Table 1. Welding parameters and their levels

\begin{tabular}{|l|c|c|c|c|}
\hline \multicolumn{1}{|c|}{ Parameter } & Notation & Level-1 & Level-2 & Level-3 \\
\hline \hline V & V & 19 & 20 & 21 \\
\hline WFS, m/min & WFS & 3 & 4 & 5 \\
\hline WS, mm/s & WS & 2 & 4 & 8 \\
\hline Alpha, degree & Alpha & 25 & 45 & 80 \\
\hline
\end{tabular}

Table 2. Taguchi orthogonal array L9

\begin{tabular}{|c|c|c|c|c|}
\hline Experimental Run & V & WFS & WS & Alpha \\
\hline \hline$\# 1$ & 1 & 1 & 1 & 1 \\
\hline$\# 2$ & 1 & 2 & 2 & 2 \\
\hline$\# 3$ & 1 & 3 & 3 & 3 \\
\hline$\# 4$ & 2 & 1 & 2 & 3 \\
\hline$\# 5$ & 2 & 2 & 3 & 1 \\
\hline$\# 6$ & 2 & 3 & 1 & 2 \\
\hline$\# 7$ & 3 & 1 & 3 & 2 \\
\hline$\# 8$ & 3 & 2 & 1 & 3 \\
\hline$\# 9$ & 3 & 3 & 2 & 1 \\
\hline
\end{tabular}


Results and discussion. The results obtained in the nine experimental tests are shown in Fig. 1. According to this figure, the average HAZ width has changed from 1.23 to $3.04 \mathrm{~mm}$ in various welding conditions. The $\mathrm{S} / \mathrm{N}$ ratio for each experiment is calculated and tabulated in Table 3. The average values of $\mathrm{S} / \mathrm{N}$ ratios of the four control factors at each of the levels are calculated and presented in Table 4. Higher the difference between their maximum and minimum values designates higher relative effect of parameter on the response [15].

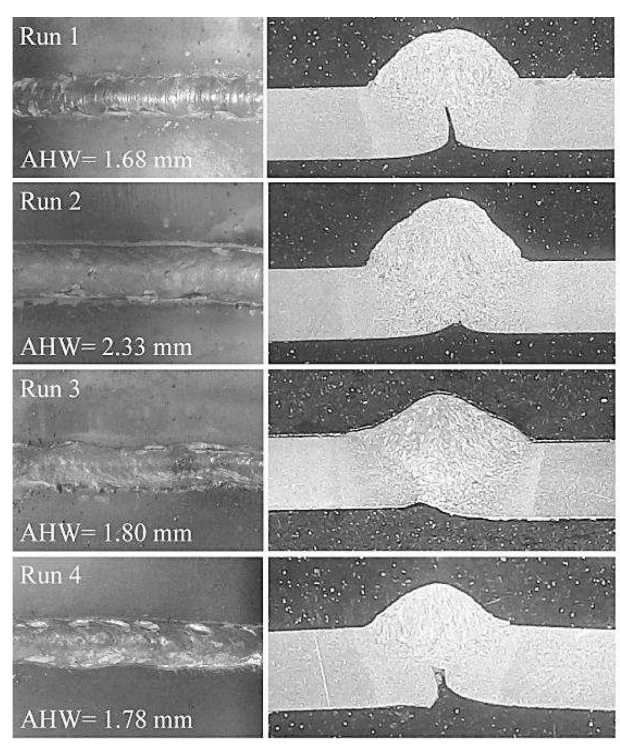

Fig. 1. The results of experimental experiments (AHW: average HAZ width).
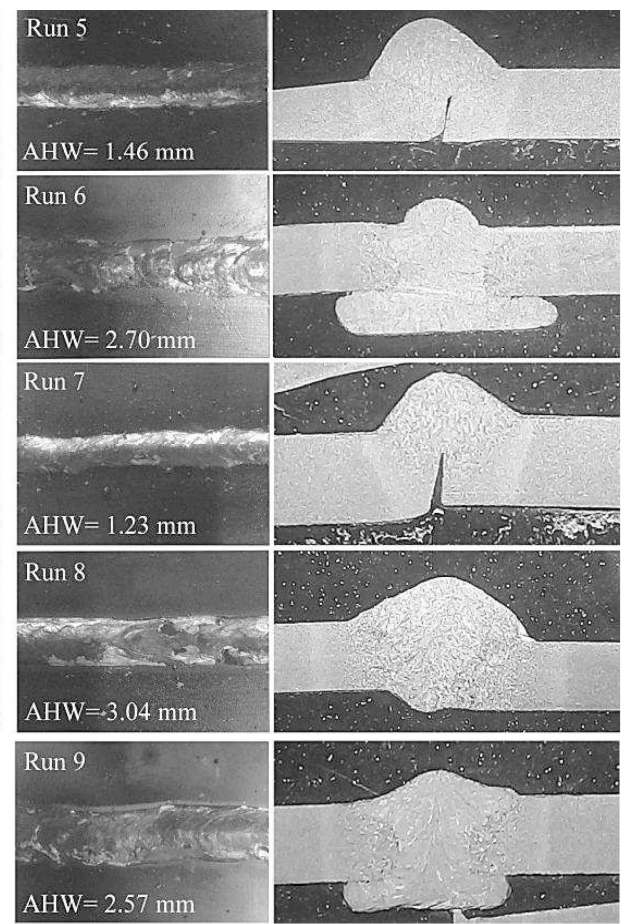
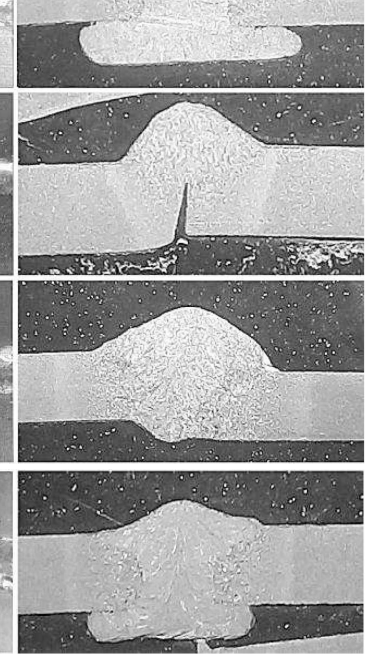

It is found from Delta values in Table 4 that the most significant parameter that affects the HAZ width is welding speed and the next is wire feeding speed. The optimal condition for minimum HAZ width (from the average $\mathrm{S} / \mathrm{N}$ values of process parameters at three levels) is V-2 $(20 \mathrm{~V})$, WFS-1 $(3 \mathrm{~m} / \mathrm{min})$, WS-3 $(8 \mathrm{~mm} / \mathrm{s})$ and Alpha-1 ( 25 degree). The main effect plots generated by Minitab 16 software in Fig. 2 show the variation in the HAZ width with change in input factors. The welding speed graph is more diverging than the other factors, so it can be assumed that welding speed is the most significant factor that affects the HAZ width, the next is wire feeding speed while arc voltage and torch angle have less effect on the HAZ width.

Table 3. The average HAZ width and the corresponding $\mathrm{S} / \mathrm{N}$ ratio

\begin{tabular}{|c|c|c|}
\hline Experimental Run & Average HAZ width, mm & S/N ratio \\
\hline \hline 1 & 1.68 & -4.51 \\
\hline 2 & 2.33 & -7.35 \\
\hline 3 & 1.80 & -5.11 \\
\hline 4 & 1.78 & -5.01 \\
\hline 5 & 1.46 & -3.29 \\
\hline 6 & 2.70 & -8.63 \\
\hline 7 & 1.23 & -1.80 \\
\hline 8 & 3.04 & -9.66 \\
\hline 9 & 2.57 & -8.20 \\
\hline
\end{tabular}


Table 4. Response Table for $\mathrm{S} / \mathrm{N}$ ratios - smaller is better

\begin{tabular}{|c|c|c|c|c|}
\hline Level & V & WFS & WS & Alpha \\
\hline 1 & -5.66 & -3.77 & -7.60 & -5.33 \\
\hline 2 & -5.64 & -6.77 & -6.85 & -5.93 \\
\hline 3 & -6.55 & -7.31 & -3.40 & -6.59 \\
\hline Delta & 0.91 & 3.54 & 4.2 & 1.26 \\
\hline Rank & 4 & 2 & 1 & 3 \\
\hline
\end{tabular}

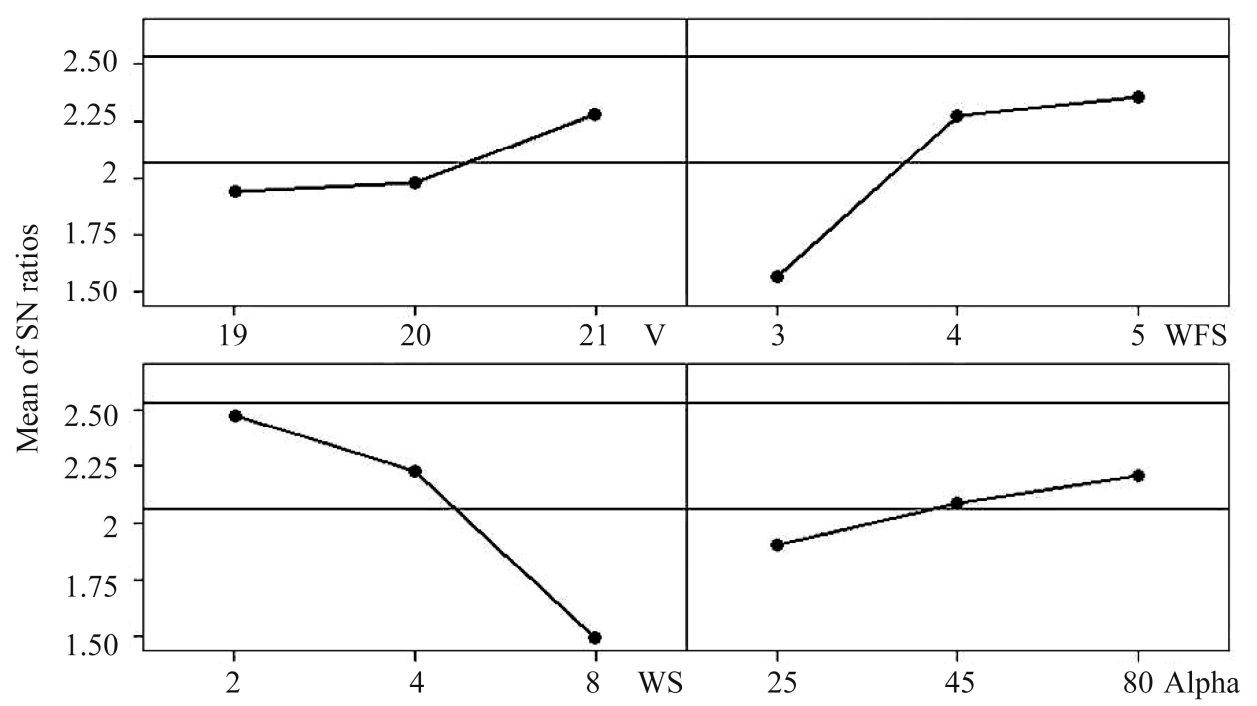

Fig. 2. Main effect plots for $\mathrm{S} / \mathrm{N}$ ratios for the $\mathrm{HAZ}$ width.

The ANOVA is a statistical tool used to analyze the $\mathrm{S} / \mathrm{N}$ ratios [16], and shows the percentage contribution of given input parameters on the measurable output parameter [17]. The ANOVA values for the $\mathrm{S} / \mathrm{N}$ ratios and Regression model are calculated at $95 \%$ confidence using Minitab 16 software and tabulated in Table 5.

Table 5. The Results of ANOVA

\begin{tabular}{|c|c|c|c|c|c|c|}
\hline Source & $\mathrm{DF}$ & Seq SS & Adj SS & Adj MS & F-Value & P-Value \\
\hline Regression & 4 & 2.78612 & 2.78612 & 0.69653 & 10.8873 & 0.020040 \\
\hline $\mathrm{V}$ & 1 & 0.17682 & 0.17682 & 0.17682 & 2.7638 & 0.171755 \\
\hline WFS & 1 & 0.94407 & 0.94407 & 0.94407 & 14.7565 & 0.018437 \\
\hline WS & 1 & 1.53562 & 1.53562 & 1.53562 & 24.0029 & 0.008048 \\
\hline Alpha & 1 & 0.12961 & 0.12961 & 0.12961 & 2.0260 & 0.227723 \\
\hline Error & 4 & 0.25591 & 0.25591 & 0.06398 & & \\
\hline Total & 8 & 3.04202 & & & & \\
\hline
\end{tabular}

Note: $S=0.252936 ; R-S q=91.59 \% ; R-S q(\operatorname{adj})=83.18 \%$.

This analysis is carried out for a significance level $(\alpha=0.05)$. From the ANOVA is observed that the welding speed is the most prominent factor which affects the HAZ width maximum with percent contribution of $50 \%$, and the next is wire feeding speed with percent contribution of $31 \%$. Percent contribution indicates the relative power of a 
factor to reduce variation. For a factor with a higher percent contribution, a small variation will have a great influence on the performance [18]. The final linear Regression model with coefficient values is represented by the Equation.

$$
\text { HAZ width }=-2.4457+0.1717 . \mathrm{V}+0.3967 . \mathrm{WFS}-0.1656 . \mathrm{WS}+0.0053 \text {. Alpha }
$$

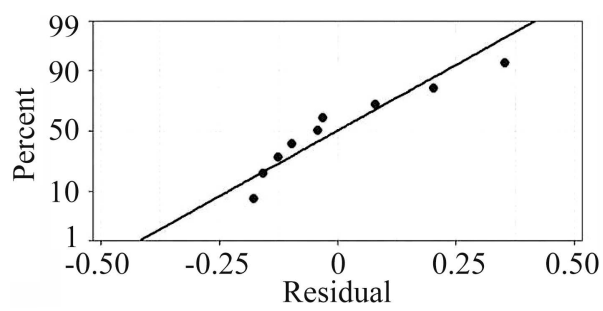

Fig. 3. Normal probability plot of residuals for the HAZ width.

The coefficient of determination (R-squared) in the ANOVA is a measure of the strength of the linear relationship between the experimental and predicted values [19]. In Regression model, the R-squared is a statistical measure of how well the Regression line approximates the real data points [20]. In the other words, it indicates the ability of a model to make predictions. The R-squared value is always between 0 and $100 \%$ and in general, a higher R-squared value is better and indicates a better fit for the Regression model. The R-squared value equal to $91.59 \%$ in this work is desirable and represents a good fit and the data closely follow the straight line. The normal probability plot of residual for the HAZ width is shown in Fig. 3. As seen, the data closely follow the straight line. If the p-value in ANOVA is less than the significance level $(\alpha=0.05)$, this means that the factor corresponding to that value of $p$ is statistically significant for the Regression model. So the value of $p$ less than 0.05 for welding speed and wire feeding speed indicates that unlike arc voltage and torch angle, they have statistically significant effect on the response HAZ width at $95 \%$ confidence level. A low $p$-value $(<0.05)$ indicates that we can reject the null hypothesis. Conversely, a larger (insignificant) $p$-value suggests that changes in the predictor are not associated with changes in the response [21]. From the ANOVA of linear Regression for the HAZ width, the p-value of Regression equation indicates that the Regression model is significant. F-ratio named after Fisher [22], is used in order to find out the significant factors that affect the response. The higher the F-value for a factor specifies that the variation of that factor makes a greater effect on the response. The highest F-value (24.0029) verifies that the welding speed is the most effective factor as ranked in Table 4 and the next is wire feeding speed with F-value of 14.7565.

\section{CONCLUSION}

A Taguchi orthogonal array L9 was used to design experiments in this work and the effect of the GMAW parameters on the HAZ width in St37-2 steel was investigated and analyzed. According to the results, the most significant parameter that affects the HAZ width is welding speed and the next is wire feeding speed while arc voltage and torch angle have less effect on the HAZ width. The ANOVA results showed that the welding speed affects the HAZ width with percent contribution of 50\%, and the next is wire feeding speed with percent contribution of $31 \%$. Also, the optimal condition predicted in this work for the minimum HAZ width was: V-2 (20 V), WFS-1 $(3 \mathrm{~m} / \mathrm{min})$, WS-3 $(8 \mathrm{~mm} / \mathrm{s})$ and Alpha-1 (25 degree).

Acknowledgements. The author would like to thank the Managing Director of Industrial and Manufacturing Company of Sava Sazeh Segal for all the facilities and financial support of this research.

1. Acquisition and pattern recognition of spectrum information of welding metal transfer / H. Guo Ming, Y. Shao Hui, C. Xin Hua, and L. Jun Yue // J. Mater. Des. - 2003. - 24. - P. 699-703.

2. Stand offs indirect estimation in GMAW / S. C. Absi Alfaro, G. C. Carvalho, and S. A. de Melo Junior // J. Mater. Process. Technol. - 2004. - 157-158. - P. 3-7. 
3. Suban M., and Tusek J. Dependence of melting rate in MIG/MAG welding on the type of shielding gas used // J. Mat. Proc. Technol. - 2001. - 119. - P. 185-192.

4. Kacar R. and Kokemli K. Effect of controlled atmosphere on the MIG-MAG arc weldment properties // J. Mater. Des. - 2005. - 26. - P. 508-516.

5. Messler $R$. W. Principles of welding, processes, physics, chemistry, and metallurgy. Chapter 3. - New York: John Wiley \& Sons, 1999.

6. Dolby R. E. Met. Const. and Brit. Weld. J. - 1971. - 3. - P. 99.

7. Harrison J. D. Why Does Low Toughness In the HAZ Matter? // The Welding Institute Seminar. - Coventry, England, 1983.

8. Fairchild D. P. Local brittle zones in structural welds / Ed.: J. Y. Koo // Welding Metallurgy of Structural Steels. - Denver: TMS, CO, 1987. - P. 303-318.

9. Haze T., and Aihara S. // Proc. $7^{\text {th }}$ Conf. on Offshore Mechanics and Arabic Engineering (OMAE), Houston, - 1988.

10. Harisson P. L. and Hant P. H. M. // Proc. Int. Conf. on Weld Failures. - London: The Welding Institute, 1988.

11. Denys R. M. // Proc. Int. Conf. on Weld Failures. - London: The Welding Institute, 1988.

12. Boniszewski T., and Watkinson F. Effect of weld microstructure on hydrogen-induced cracking in transformable steels // Met. Mater. - 1973. - 7. - P. 91-96/145-151.

13. Ambekar S. D. and Wadhokar S. R. Influence of process parameters on depth of penetration in GMAW process by using Taguchi method // Int. J. Sci. Res. - 2015. - 4. - P. 3065-3069.

14. Khalkhali A., Noraie H., and Sarmadi $M$. Sensitivity analysis and optimization of hot-stamping process of automotive components using analysis of variance and Taguchi technique // Proc. of the Institution of Mechan. Eng., Part E // J. Process Mech. Eng. - 2016.

15. Sailender M., Chandra Mohan Reddy G., and Venkatesh S. Influences of process parameters on heat affected zone in submerged arc welding of low carbon steel // Ame. J. Mater. Sci. - 2016. - 6. - P. 102-108.

16. Kumar R. and Kumar S. Study of mechanical properties in mild steel using metal inert gas welding // Int. J. Res. Eng. Techn. - 2014. - 3. - P. 751-756.

17. Parametric optimization of GTAW welding using Taguchi and ANOVA / A. S. Jadon, N. S. Kushwah, P. Agrawal, and P. Mittal // Int. J. Res. Appl. Sci. Eng. Technol. - 2017. - 5. - P. 650-655.

18. The use of Taguchi method to determine factors affecting the performance of destination sequence distance vector routing protocol in mobile Ad Hoc networks / H. Mohamed, M. H. Lee, M. Sarahintu, S. Salleh, and B. Sanugi // J. Math. Stat. - 2008. - 4. - P. 194-198.

19. Rajendran A., Thirugnanam M., and Thangavelu $V$. Statistical evaluation of medium compoents by Plackett-Burman experimental design and kinetic modeling of lipase production by Pseudomonas fluorescens // Ind. J. Biotechnol. - 2007. - 6. - P. 469-478.

20. Patil S. A., Baratzadeh F., and Lankarani $H$. Modeling of the weld strength in spot weld using regression analysis of the stress parameters based on the simulation study // J. Mat. Sci. Res. - 2017. - 6. - P. 51-61.

21. Design-Expert software, Version 6, User's Guide, Technical Manual, Stat-Ease Inc., Minneapolis, $\mathrm{MN}-2000$.

22. Lindman H. R. Analysis of variance in experimental design, $1^{\text {st }}$ Ed. - New York: SpringerVerlag, Inc. - 1992. 